\title{
PEMERIKSAAN KESEIMBANGAN DINAMIS PASIEN LANJUT USIA DENGAN BERG BALANCE SCALE BERBASIS WEB
}

\author{
Novilia Purwita Putri, Aris Rakhmadi \\ Program Studi Informatika \\ Universitas Muhammadiyah Surakarta (UMS) Surakarta, Indonesia \\ noviliapputri23@gmail.com, aris.rakhmadi@ums.ac.id
}

Pemeriksaan keseimbangan dinamis terhadap pasien lanjut usia menggunakan metode berg balance scale yang dilakukan oleh terapis sampai saat ini masih menggunakan kertas. Penggunaan media konvensional mempunyai keterbatasan yang dapat menimbulkan beberapa permasalahan seperti hilangnya kertas hasil data pemeriksaan serta sulitnya pencarian data. Tujuan dari pembuatan sistem ini yaitu memberikan sebuah alternatif dengan membuat formulir pemeriksaan keseimbangan dinamis dengan berg balance scale berbasis web. Pemeriksaan berbasis web ini mempunyai fitur berupa sebuah formulir yang dapat diisi dengan menggunakan komputer sehingga data dapat tersimpan rapi. Adanya alternatif tersebut dapat membantu penginputan serta pengarsipan data pemeriksaan yang telah dilakukan oleh fisioterapis. Pembuatan formulir berg balance scale berbasis web ini menggunakan metode waterfall dan bahasa pemrograman PHP dengan tampilan bootstrap. MySQL digunakan untuk mengelola database. Tools dan editor yang digunakan adalah xampp dan sublime. Teknik yang digunakan untuk pengumpulan data yakni observasi, wawancara dan kuesioner. Hasil penelitian ini adalah sebuah sistem yang mencakup formulir berg balance scale, grafik data pasien dan pemeriksaan, laporan data pemeriksaan yang dapat diunduh dan dicetak, tabel pengujian black box serta data hasil kuesioner.

Kata Kunci : Berg balance scale, Keseimbangan, Lanjut usia, MySQL, Web

\section{PENDAHULUAN}

Lanjut usia atau sering disebut lansia adalah seseorang yang telah mengalami penuaan ditandai dengan menurunnya beberapa fungsi tubuh. Banyaknya penurunan fungsi tubuh yang dialami seorang lansia, menyebabkan terjadinya penurunan kualitas hidup pada lansia. World Health Organization (WHO) menggolongkan lansia menjadi 4 yaitu usia pertengahan (middle age) adalah 45-59 tahun, usia lanjut (elderly) adalah 60-74 tahun, lanjut usia tua (old) adalah 75-90 tahun, dan usia sangat tua (very old) diatas 90 tahun.

Zaman sekarang seorang lansia kurang memperhatikan kemampuan fisiknya sehingga lansia dapat mengalami gangguan keseimbangan dan penurunan fungsi yang berkaitan dengan keseimbangan tubuhnya, salah satu contohnya adalah penurunan keseimbangan dinamis. Keseimbangan dinamis merupakan kemampuan untuk mempertahankan kesetimbangan ketika bergerak. Penilaian keseimbangan dinamis dapat dilakukan dengan menggunakan Berg Balance Scale atau BBS. Penilaian keseimbangan dinamis terhadap pasien lansia biasanya dilakukan oleh tenaga kesehatan yang memiliki spesifikasi dalam kasus lansia yaitu Fisioterapi Geriatri. Data saat melakukan penilaian keseimbangan dinamis untuk sementara masih menggunakan formulir dalam bentuk kertas yang selanjutnya data-data tersebut diarsipkan dan dikumpulkan menjadi satu. Hal ini menjadi hambatan bagi praktisi, akademisi bahkan mahasiswa fisioterapi dalam menyimpan data pasien, seperti yang telah dialami oleh Fakultas Ilmu Kesehatan Jurusan Fisioterapi di Universitas Muhammadiyah Surakarta.

Permasalahan yang timbul adalah jika suatu saat data tersebut hilang atau terbakar 
maka dapat mengakibatkan sulitnya dalam pencarian data apabila dibutuhkan. Berdasarkan permasalahan tersebut, maka diberikan sebuah alternatif untuk mengantisipasi kejadian yang tidak diinginkan yaitu dengan adanya inovasi baru untuk membuat sebuah formulir pemeriksaan keseimbangan dinamis pasien lansia dengan BBS berbasis web. Adanya alternatif pembuatan formulir berbasis web tersebut dapat membantu pekerjaan tenaga kesehatan fisioterapi dalam menginput dan mengarsipkan data pemeriksaan yang telah dilakukan. Data pemeriksaan tersebut disimpan di dalam database sehingga fisioterapi tidak kesulitan dalam melakukan pencarian data apabila dibutuhkan. Pembuatan formulir berbasis web ini menggunakan bahasa pemrograman hypertext preprocessor (PHP) dengan database MySQL dan bootstrap sebagai tampilan user interface.

Adit Prasetyo dan Nanang Indardi (2015) menjelaskan berdasarkan rincian tes keseimbangan tubuh yang telah dilakukan dengan skor 41-56 mengalami resiko jatuh rendah, skor 21-40 mengalami resiko jatuh menengah dan skor 0-20 mengalami resiko jatuh tinggi. Berdasarkan interpretasi BBS, didapatkan bahwa hasil pre test menunjukkan lanjut usia di Panti Mulyo Sragen memiliki resiko jatuh rendah dengan skor minimal dan hasil post test menunjukkan skor maksimal dengan resiko jatuh rendah. [1]

M. Malik Prigianata (2013) menjelaskan data KMS (Kartu Menuju Sehat) sangat penting untuk keperluan tindakan di POSYANDU dan juga membantu dinas kesehatan dalam menentukan kebijakan berdasarkan data yang tersebar di berbagai POSYANDU. Kelebihan dari pembuatan sistem informasi ini terdapat KMS digital yang dapat diakses melalui website dan melalui sms serta dinas kesehatan dapat mengetahui laporan dengan cepat karena dapat diakses secara real time. [2]

Shantanu Nundy, Gaurav Singal, dkk (2012) menjelaskan alat berbasis web yang dirancang untuk menerjemahkan pedoman kesehatan preventif bagi masyarakat dapat menjadi tujuan utama dalam memperbaiki penyampaian layanan kesehatan dan mendorong promosi kesehatan. Situs web yang dikembangkan tersedia untuk umum baik praktisi maupun masyarakat. [3]

Stephen Downs, Jodie Marquez, dkk (2014) menjelaskan berdasarkan pencarian yang telah dilakukan menghasilkan 17 studi yang relevan dari total data 1.363 peserta lansia. Nilai rata-rata BBS berkisar antara 37 sampai 55 dari maksimal nilai 56. Lansia dari kelompok kesehatan memiliki keseimbangan yang rata-rata sedang berdasarkan penilaian menggunakan skala BBS, nilai keseimbangan pada lansia dapat berubah dan lebih bervariasi seiring bertambahnya usia. [4]

\section{DASAR TEORI DAN TINJAUAN PUSTAKA}

Berg Balance Scale adalah suatu tes klinis yang banyak digunakan untuk pengukuran keseimbangan seseorang misalnya keseimbangan dinamis pada lansia ataupun pasien dengan riwayat sakit. [5]

Skala BBS dikembangkan pada tahun 1989 dengan menggunakan proses wawancara terhadap pasien dan professional kesehatan. Terdapat 38 item tes keseimbangan dinamis yang pada awalnya dipilih dan kemudian disempurnakan melalui wawancara serta uji coba lebih lanjut sehingga tersisa 14 item yang digunakan. Dari masing-masing item tersebut terdapat bobot penilaian 0 sampai 4 dan dengan nilai maksimum 56, yang mana skor lebih tinggi menunjukkan bahwa keseimbangan dinamis lansia itu baik. [6]

\section{METODE}

Penelitian ini menggunakan 2 metode yaitu Metode Waterfall sebagai pengembangan sistem informasi dan Metode Berg Balance Scale sebagai formulir pemeriksaan keseimbangan dinamis.

\section{A. Metode Waterfall}

Metode Waterfall merupakan metode pengembangan perangkat lunak terstruktur yang paling dikenal dan banyak digunakan secara luas, tidak hanya di lingkup akademisi tetapi juga industri. Metode Waterfall sering disebut dengan classic life cycle (Pressman, 
2010). [7] Metode Waterfall dalam penelitian ini hanya menggunakan 4 tahapan yang ditunjukkan pada Gambar 1. [8]

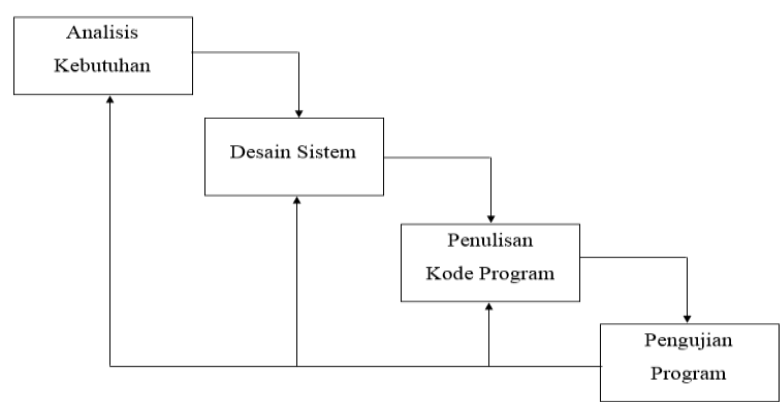

Gambar 1. Metode Waterfall

\section{Analisis Kebutuhan}

Tahap ini merupakan tahapan dimana sistem harus menyediakan formulir untuk melakukan penilaian keseimbangan dinamis serta kolom saran untuk penulisan jangka pelatihan dan jenis pelatihan bagi pasien. Pengumpulan data penilaian pasien dilakukan dengan metode observasi langsung ke tempat lansia dan metode wawancara dengan narasumber fisioterapi mengenai pengisian formulir serta pelatihan yang diperlukan.

2. Desain Sistem

Tahap ini dilakukan sebelum melakukan penulisan kode program yang bertujuan untuk memberikan gambaran apa yang harus dikerjakan dan ditampilkan dalam sistem. Tahap ini membantu dalam menspesifikasi kebutuhan sistem secara keseluruhan dan harus dapat dipahami oleh fisioterapis sehingga mudah dalam melakukan pengisian terhadap penilaian tes keseimbangan dinamis.

2.1 Use Case Diagram merupakan sebuah hubungan interaksi antara pengguna dengan sistem yang menggambarkan fungsionalitas dalam sistem. Terdapat 2 aktor pada use case diagram ini :

a. Admin, bertugas mengolah data terapis mulai dari tambah, ubah, hapus, serta lihat data terapis. Dapat mengolah data pasien serta data pemeriksaan yang telah diinputkan oleh terapis mulai dari ubah, hapus dan lihat data.

b. Terapis, bertugas mengolah data pasien mulai dari tambah, ubah, hapus, serta lihat data, mengolah data penilaian pemeriksaan pasien yakni tambah, ubah, hapus, serta lihat data, dan mencetak laporan hasil penilaian. Proses Use Case Diagram ditunjukkan pada Gambar 2.

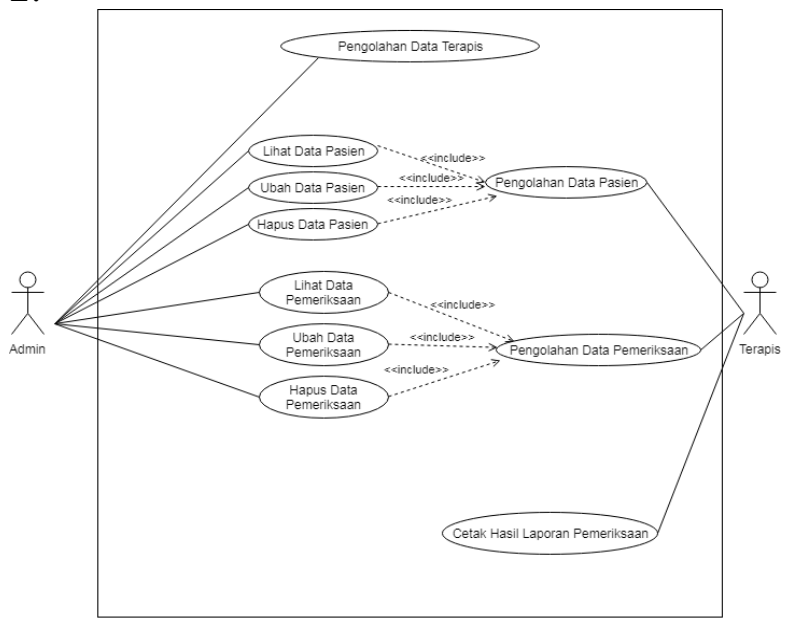

Gambar 2. Use Case Diagram

\subsection{Diagram Activity}

Diagram Activity merupakan gambaran alur pada sebuah sistem berdasarkan pada use case diagram. Pembuatan diagram dimaksudkan untuk menggambarkan aktivitas yang dilakukan pada sistem dalam program formulir pemeriksaan ini seperti pengolahan data terapis oleh admin sampai mencetak laporan hasil pemeriksaan oleh terapis. Gambaran dari diagram activity dari sistem yang dibuat ditunjukkan pada Gambar 3.



Gambar 3. Diagram Activity

\subsection{Tabel Relasi}

Penelitian ini membutuhan sebuah database dengan nama pemeriksaan yang dibangun menggunakan software DB designer, kemudian diimplementasikan dalam Database MySQL. Database ini terdiri dari beberapa tabel yaitu tabel admin, tabel beranda, tabel soal, tabel jawab, tabel terapis, tabel pasien, dan tabel 
formulir. Hubungan relasi antar tabel ditunjukkan pada Gambar 4.
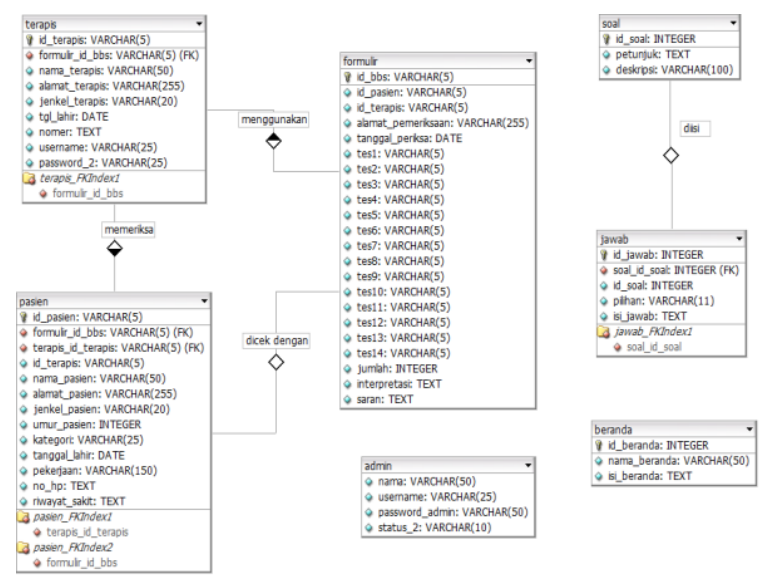

Gambar 4. Tabel Relasi

\section{Penulisan Kode Program}

Tahap ini dilakukan dengan menggunakan bahasa pemrograman PHP (hypertext preprocessor) dan database MySQL. Kode program ditulis sesuai dengan kebutuhan penilaian oleh fisioterapis berupa formulir dari BBS. Setelah pengkodean selesai dilanjutkan dengan pengujian terhadap sistem yang telah dibuat. Salah satu kode program untuk menjumlahkan hasil pemeriksaan dan kondisi interpretasi berdasarkan hasil akhir penilaian untuk mengetahui resiko jatuh pada lansia. Kode program ditunjukkan pada Gambar 5.

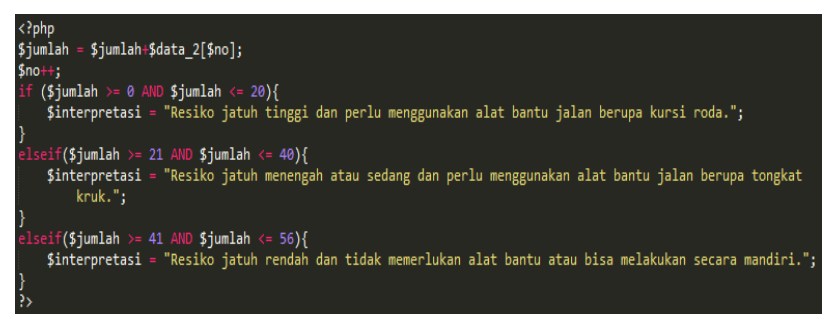

Gambar 5. Kode Program

\section{Pengujian Program}

Tahap ini dilakukan dengan cara beberapa terapis atau mahasiswa fisioterapi menggunakan langsung sistem tersebut untuk melakukan penilaian yang dilakukan di Panti Jompo Aisyiyah Surakarta dan melakukan metode kuesioner untuk mengetahui apakah sistem sudah berjalan dengan baik atau belum serta apakah sistem yang dibuat sudah cukup membantu terapis dalam melakukan pemeriksaan.

\section{B. Metode Berg Balance Scale}

Metode ini digunakan untuk mengukur keseimbangan dinamis antara lansia dengan penurunan kinerja beberapa fungsi tubuh. Penilaian menggunakan formulir BBS ini terdapat beberapa item penilaian yang ditunjukkan pada Gambar 6.

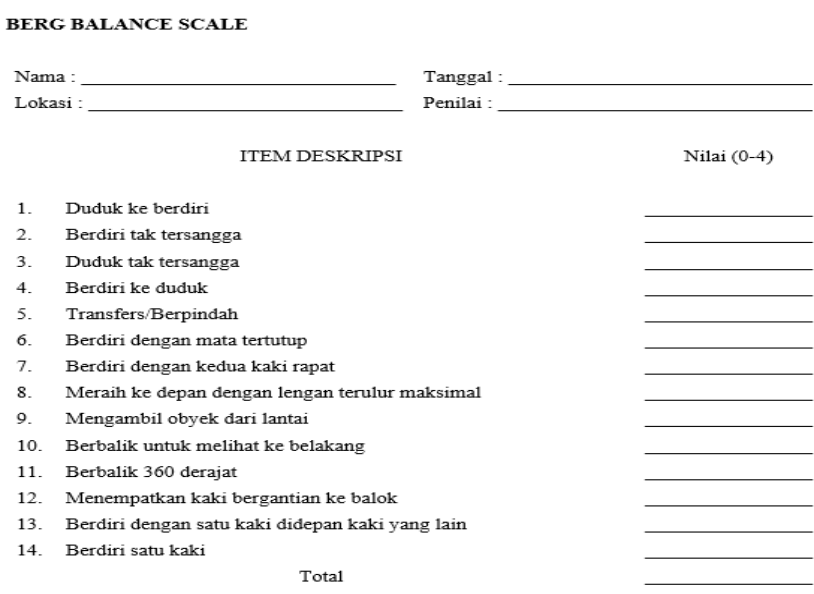

Gambar 6. Formulir Berg Balance Scale

\section{HASIL DAN PEMBAHASAN}

Sistem yang dihasilkan dari penelitian ini mencakup sebuah formulir berg balance scale berbasis web yang mempunyai 2 halaman utama yaitu halaman bagian admin dan bagian terapis. Halaman beranda pada admin menampilkan jumlah pasien dan jumlah pemeriksaan beserta dengan grafiknya sesuai data yang telah diinputkan oleh terapis. Detail tampilan halaman beranda admin ditunjukkan pada Gambar 7.

\section{Beranda}

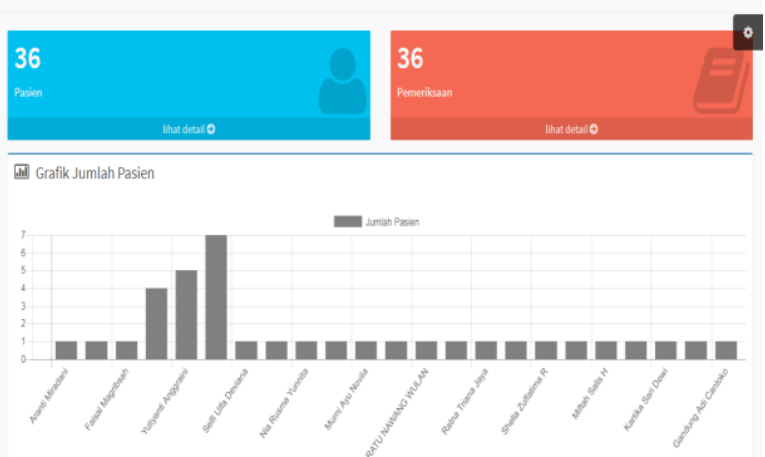

Gambar 7. Halaman Beranda Admin 
Admin dapat melihat laporan jumlah pasien dan jumlah pemeriksaan perterapis yang bisa langsung terelasi sesuai dengan nama terapis yang dipilih serta dapat mencari data sesuai yang diinginkan berdasarkan nama terapis atau field yang lain. Ditunjuk kan pada Gambar 8.



Gambar 8. Pencarian berdasarkan Nama Terapis

Sistem ini menampilkan beberapa informasi terkait dengan formulir BBS yang ada di dalam tampilan beranda terapis yang telah login sesuai dengan username dan password sesuai inputan oleh admin. Ditunjukkan pada Gambar 9.

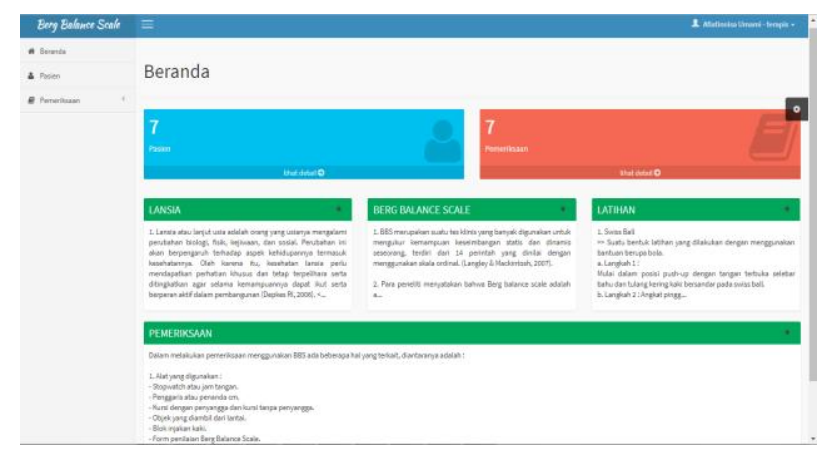

Gambar 9. Tampilan Beranda Terapis

Hasil pemeriksaan pasien dapat dilihat, diunduh serta dapat langsung dicetak yang ditunjukkan pada Gambar 10.

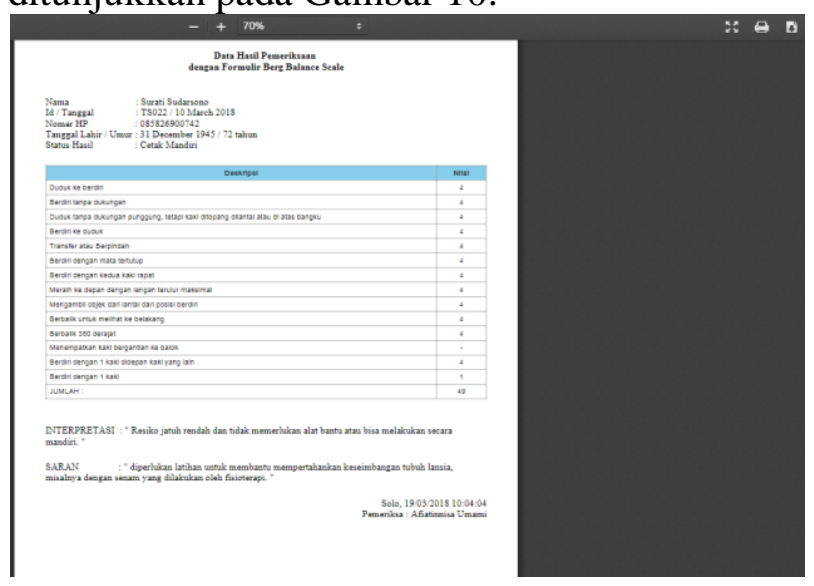

Gambar 10. PDF Hasil Pemeriksaan
Pengujian sistem ini dilakukan dengan 2 cara yaitu dengan metode black box dan tes kuesioner yang diberikan ke beberapa mahasiswa fisioterapi. Pengujian yang dilakukan bertujuan untuk mengetahui apakah sistem yang dibuat berjalan dengan baik. Untuk itu pengujian ini dilakukan berdasarkan pada user interface, input, output dan struktur data dalam sistem. Pengujian dengan metode black box ditunjukkan pada Tabel 1 .

Tabel 1. Hasil Pengujian Black Box

\begin{tabular}{|c|c|c|c|}
\hline Module & Test Case & $\begin{array}{c}\text { Hasil yang } \\
\text { Diharapkan }\end{array}$ & Hasil \\
\hline \multirow{2}{*}{ Login } & $\begin{array}{l}\text { User \& Password } \\
\text { Benar }\end{array}$ & $\begin{array}{l}\text { Muncul Notifikasi } \\
\text { Berhasil Login }\end{array}$ & Valid \\
\hline & $\begin{array}{l}\text { User \& Password } \\
\text { Salah }\end{array}$ & $\begin{array}{l}\text { Muncul Notifikasi } \\
\text { Gagal Login }\end{array}$ & Valid \\
\hline \multirow{5}{*}{$\begin{array}{l}\text { Pengolahan } \\
\text { Data } \\
\text { Terapis }\end{array}$} & $\begin{array}{l}\text { Klik Tambah } \\
\text { Terapis }\end{array}$ & $\begin{array}{l}\text { Menampilkan } \\
\text { Halaman untuk } \\
\text { Tambah Data } \\
\text { Terapis }\end{array}$ & Valid \\
\hline & $\begin{array}{l}\text { Menambahkan } \\
\text { Data Terapis } \\
\text { dengan Benar }\end{array}$ & $\begin{array}{l}\text { Data Tersimpan di } \\
\text { Database dan } \\
\text { Dapat Tampil di } \\
\text { Sistem }\end{array}$ & Valid \\
\hline & $\begin{array}{l}\text { Menambahkan } \\
\text { Data Terapis } \\
\text { dengan Nama } \\
\text { Tidak } \\
\text { Diinputkan }\end{array}$ & $\begin{array}{l}\text { Muncul Notifikasi } \\
\text { untuk Mengisi } \\
\text { Kolom Nama dan } \\
\text { Data Belum } \\
\text { Tersimpan di } \\
\text { Database }\end{array}$ & Valid \\
\hline & $\begin{array}{l}\text { Klik Edit } \\
\text { Terapis }\end{array}$ & $\begin{array}{l}\text { Menampilkan } \\
\text { Halaman untuk } \\
\text { Ubah Data } \\
\text { Terapis }\end{array}$ & Valid \\
\hline & $\begin{array}{l}\text { Klik Hapus } \\
\text { Terapis }\end{array}$ & $\begin{array}{l}\text { Muncul Notifikasi } \\
\text { Hapus Terapis } \\
\text { dan Data } \\
\text { Terhapus }\end{array}$ & Valid \\
\hline \multirow{2}{*}{$\begin{array}{l}\text { Pengolahan } \\
\text { Data } \\
\text { Pasien }\end{array}$} & $\begin{array}{l}\text { Klik Tambah } \\
\text { Pasien }\end{array}$ & $\begin{array}{l}\text { Menampilkan } \\
\text { Halaman untuk } \\
\text { Tambah Data } \\
\text { Pasien }\end{array}$ & Valid \\
\hline & $\begin{array}{l}\text { Menambahkan } \\
\text { Data Pasien } \\
\text { dengan Benar }\end{array}$ & $\begin{array}{l}\text { Data Tersimpan di } \\
\text { Database dan } \\
\text { Dapat Tampil di } \\
\text { Sistem }\end{array}$ & Valid \\
\hline
\end{tabular}




\begin{tabular}{|c|c|c|c|}
\hline Module & Test Case & $\begin{array}{c}\text { Hasil yang } \\
\text { Diharapkan }\end{array}$ & Hasil \\
\hline & $\begin{array}{l}\text { Menambahkan } \\
\text { Data Pasien } \\
\text { dengan Nama } \\
\text { Tidak } \\
\text { Diinputkan }\end{array}$ & $\begin{array}{l}\text { Muncul } \\
\text { Notifikasi untuk } \\
\text { Mengisi Kolom } \\
\text { Nama dan Data } \\
\text { Belum } \\
\text { Tersimpan di } \\
\text { Database }\end{array}$ & Valid \\
\hline & $\begin{array}{l}\text { Klik Edit } \\
\text { Pasien }\end{array}$ & $\begin{array}{l}\text { Menampilkan } \\
\text { Halaman untuk } \\
\text { Ubah Data } \\
\text { Pasien }\end{array}$ & Valid \\
\hline & $\begin{array}{l}\text { Klik Hapus } \\
\text { Pasien }\end{array}$ & $\begin{array}{l}\text { Muncul } \\
\text { Notifikasi Hapus } \\
\text { Pasien dan Data } \\
\text { Terhapus }\end{array}$ & Valid \\
\hline \multirow{5}{*}{$\begin{array}{l}\text { Pengolahan } \\
\text { Data } \\
\text { Pemeriksaan }\end{array}$} & $\begin{array}{l}\text { Klik Tambah } \\
\text { Pemeriksaan }\end{array}$ & $\begin{array}{l}\text { Menampilkan } \\
\text { Halaman untuk } \\
\text { Tambah Data } \\
\text { Pemeriksaan }\end{array}$ & Valid \\
\hline & $\begin{array}{l}\text { Menambahkan } \\
\text { Data } \\
\text { Pemeriksaan } \\
\text { dengan Benar }\end{array}$ & $\begin{array}{l}\text { Data Tersimpan } \\
\text { di Database dan } \\
\text { Dapat Tampil di } \\
\text { Sistem }\end{array}$ & Valid \\
\hline & $\begin{array}{l}\text { Menambahkan } \\
\text { Data } \\
\text { Pemeriksaan } \\
\text { dengan Alamat } \\
\text { Tidak } \\
\text { Diinputkan }\end{array}$ & $\begin{array}{l}\text { Muncul } \\
\text { Notifikasi untuk } \\
\text { Mengisi Kolom } \\
\text { Alamat dan Data } \\
\text { Belum } \\
\text { Tersimpan di } \\
\text { Database }\end{array}$ & Valid \\
\hline & $\begin{array}{l}\text { Klik Edit } \\
\text { Pasien }\end{array}$ & $\begin{array}{l}\text { Menampilkan } \\
\text { Halaman untuk } \\
\text { Ubah Data } \\
\text { Pasien }\end{array}$ & Valid \\
\hline & $\begin{array}{l}\text { Klik Hapus } \\
\text { Pasien }\end{array}$ & $\begin{array}{l}\text { Muncul } \\
\text { Notifikasi Hapus } \\
\text { Pasien dan Data } \\
\text { Terhapus }\end{array}$ & Valid \\
\hline \multirow{2}{*}{$\begin{array}{l}\text { Laporan } \\
\text { Hasil } \\
\text { Pemeriksaan }\end{array}$} & $\begin{array}{l}\text { Klik Detail } \\
\text { Data } \\
\text { Pemeriksaan }\end{array}$ & $\begin{array}{l}\text { Muncul PDF } \\
\text { Hasil } \\
\text { Pemeriksaan } \\
\text { yang Dapat } \\
\text { Diunduh dan } \\
\text { Dicetak }\end{array}$ & Valid \\
\hline & $\begin{array}{l}\text { Klik Laporan } \\
\text { Per Terapis }\end{array}$ & $\begin{array}{l}\text { Muncul Jumlah } \\
\text { Data Laporan } \\
\text { Perterapis dan } \\
\text { Dapat Dilihat } \\
\text { Secara Detail }\end{array}$ & Valid \\
\hline Pencarian & $\begin{array}{l}\text { Mencari Data } \\
\text { di Kolom } \\
\text { Pencarian }\end{array}$ & $\begin{array}{l}\text { Menampilkan Data } \\
\text { Sesuai Kata yang } \\
\text { Dicari }\end{array}$ & Valid \\
\hline Logout & $\begin{array}{l}\text { Klik Tombol } \\
\text { Logout }\end{array}$ & $\begin{array}{l}\text { Muncul Notifikasi } \\
\text { Berhasil Logout }\end{array}$ & Valid \\
\hline
\end{tabular}

sistem ini sudah berjalan dengan baik dan tidak ditemukan kesalahan dalam sistem setelah diperbaiki beberapa keselahan yang ada.

Pengujian pada sistem melibatkan beberapa Mahasiswa Fisioterapi di Universitas Muhammadiyah Surakarta untuk mencoba secara langsung kinerja dari sistem ini. Sistem sudah berjalan dengan baik dan mendapatkan respon yang baik pula.

Pernyataan tabel pengisian kuesioner untuk calon pengguna. Data hasil kuesioner dihitung menggunakan rumus persamaan 1 .

Presentase $=\left(\sum\right.$ skor $\left.\times 100 \%\right) /$ Smax

Untuk menghitung nilai Smax yaitu dengan rumus persamaan 2 . Smax $=\sum$ Responden $\times 5$

Keterangan : 5 didapat dari nilai SS.

Jadi untuk nilai Smax dalam kuesioner ini yaitu $35 \times 5=175$.

Tabel 2. Hasil Kuesioner pengujian sistem Status Admin

\begin{tabular}{|c|c|c|c|c|c|c|c|c|}
\hline \multirow[b]{2}{*}{ No } & \multirow[b]{2}{*}{$\begin{array}{c}\text { Kod } \\
\text { e }\end{array}$} & \multicolumn{5}{|c|}{ Jumlah Jawaban } & \multirow[b]{2}{*}{$\begin{array}{c}\text { Tota } \\
1 \\
\text { Skor }\end{array}$} & \multirow[b]{2}{*}{$\begin{array}{c}\text { Presentas } \\
\text { e }\end{array}$} \\
\hline & & $\begin{array}{c}S \\
S \\
(5 \\
)\end{array}$ & $\begin{array}{c}S \\
(4 \\
)\end{array}$ & $\begin{array}{c}\mathbf{N} \\
(3 \\
)\end{array}$ & $\begin{array}{l}\text { TS } \\
\text { (2) }\end{array}$ & $\begin{array}{c}\text { ST } \\
\text { S } \\
(1)\end{array}$ & & \\
\hline 1 & P1 & $\begin{array}{l}1 \\
3 \\
\end{array}$ & $\begin{array}{l}2 \\
0 \\
\end{array}$ & 2 & 0 & 0 & 151 & $86,3 \%$ \\
\hline 2 & $\mathrm{P} 2$ & $\begin{array}{l}1 \\
1\end{array}$ & $\begin{array}{l}2 \\
2 \\
\end{array}$ & 2 & 0 & 0 & 149 & $85,1 \%$ \\
\hline 3 & P3 & $\begin{array}{l}2 \\
3 \\
\end{array}$ & $\begin{array}{l}1 \\
2 \\
\end{array}$ & 0 & 0 & 0 & 163 & $93,1 \%$ \\
\hline 4 & $\mathrm{P} 4$ & $\begin{array}{l}2 \\
4 \\
\end{array}$ & 7 & 4 & 0 & 0 & 160 & $91,4 \%$ \\
\hline 5 & P5 & $\begin{array}{l}2 \\
4 \\
\end{array}$ & $\begin{array}{l}1 \\
0 \\
\end{array}$ & 1 & 0 & 0 & 163 & $93,1 \%$ \\
\hline \multicolumn{8}{|c|}{ Rata-rata Presentase } & $89,8 \%$ \\
\hline
\end{tabular}

Berdasarkan hasil pengujian menggunakan metode black box, dapat disimpulkan bahwa 
Tabel 3. Hasil Kuesioner pengujian sistem Status Terapis

\begin{tabular}{|c|c|c|c|c|c|c|c|c|}
\hline \multirow{2}{*}{$\begin{array}{l}\mathbf{N} \\
\mathbf{0}\end{array}$} & \multirow{2}{*}{$\begin{array}{l}\text { Kod } \\
\text { e }\end{array}$} & \multicolumn{5}{|c|}{ Jumlah Jawaban } & \multirow{2}{*}{$\begin{array}{l}\text { Total } \\
\text { Skor }\end{array}$} & \multirow{2}{*}{$\begin{array}{l}\text { Presen } \\
\text { tase }\end{array}$} \\
\hline & & $\begin{array}{l}\text { SS } \\
\text { (5) }\end{array}$ & $\begin{array}{c}S \\
(4)\end{array}$ & $\begin{array}{c}\mathbf{N} \\
\mathbf{( 3} \\
\mathbf{)}\end{array}$ & $\begin{array}{l}\mathbf{T} \\
\mathbf{S} \\
(\mathbf{2} \\
)\end{array}$ & $\begin{array}{c}\text { ST } \\
\text { S } \\
\text { (1) }\end{array}$ & & \\
\hline 1 & $\mathrm{P} 1$ & 15 & 18 & 2 & 0 & 0 & 153 & $87,4 \%$ \\
\hline 2 & $\mathrm{P} 2$ & 9 & 21 & 5 & 0 & 0 & 144 & $82,3 \%$ \\
\hline 3 & P3 & 24 & 11 & 0 & 0 & 0 & 164 & $93,7 \%$ \\
\hline 4 & $\mathrm{P} 4$ & 24 & 8 & 3 & 0 & 0 & 161 & $92 \%$ \\
\hline 5 & P5 & 24 & 10 & 1 & 0 & 0 & 163 & $93,1 \%$ \\
\hline \multicolumn{8}{|c|}{ Rata-rata Presentase } & $\mathbf{8 9 , 7 \%}$ \\
\hline
\end{tabular}

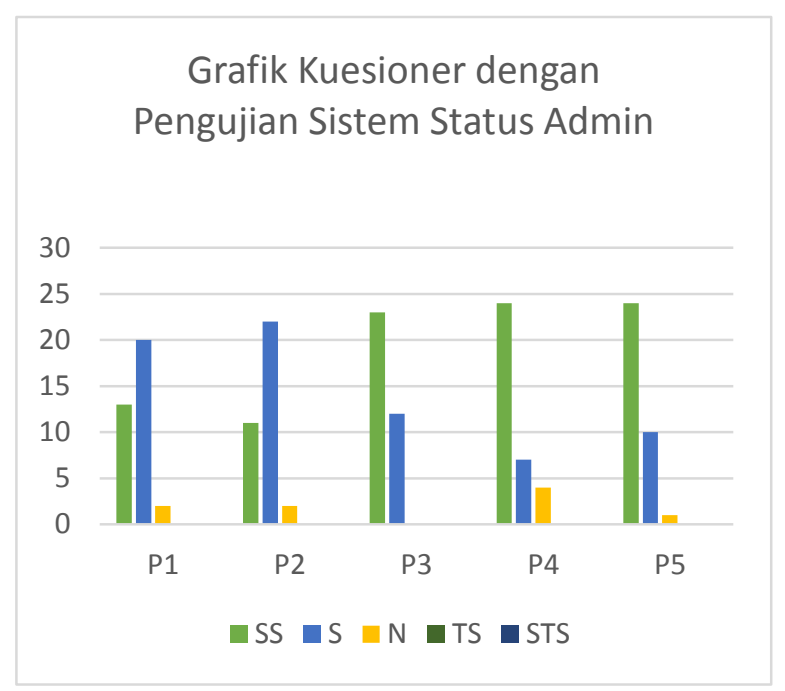

Gambar 11. Grafik Kuesioner Admin

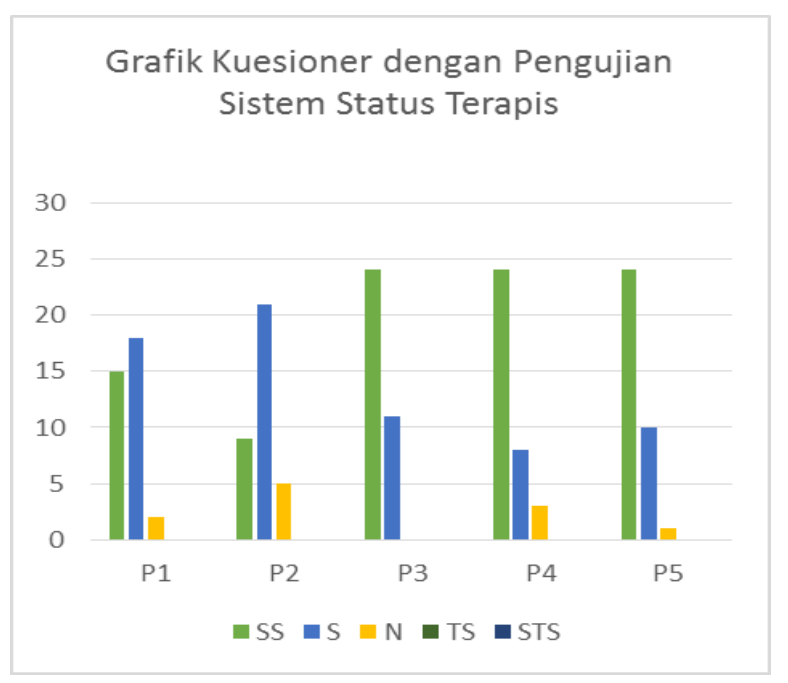

Gambar 12. Grafik Kuesioner Terapis
Keterangan :

\section{A. Admin}

P1. Sistem mudah digunakan atau dioperasikan.

P2. Tampilan halaman login dan halaman admin menarik.

P3. Sistem memberi kemudahan pengelolaan data terapis, pasien dan pemeriksaan.

P4. Sistem memberikan informasi secara detail.

P5. Informasi yang ada di dalam sistem mudah dimengerti.

\section{B. Terapis}

P1. Sistem mudah digunakan atau dioperasikan.

P2. Tampilan halaman login dan halaman terapis menarik.

P3. Sistem memberi kemudahan pengelolaan data pasien dan pemeriksaan.

P4. Sistem memberikan informasi secara detail.

P5. Informasi yang ada di dalam sistem mudah dimengerti.

Berdasarkan hasil pengujian black box yang telah dilakukan menunjukkan bahwa sistem ini sudah berjalan dengan baik. Presentase pengujian dengan kuesioner didapatkan hasil $89,8 \%$ bagi Admin dan $89,7 \%$ bagi Terapis. Presentase tersebut menunjukkan bahwa pengguna sebagian besar setuju dan terbantu dengan adanya sistem ini yang dapat digunakan untuk mengelola data pemeriksaan yang awalnya berupa formulir kertas menjadi formulir berbasis web sehingga data pemeriksaannya tersimpan dengan baik dan rapi.

\section{PENUTUP}

Sistem Pemeriksaan Keseimbangan Dinamis Pasien Lanjut Usia dengan Berg Balance Scale Berbasis Web yang telah dibuat dapat membantu Mahasiswa Fisioterapi atau Fisioterapis dalam melakukan penilaian terhadap keseimbangan dinamis lansia yang semula dengan formulir kertas diubah menjadi formulir berbasis web. Sistem lebih baik jika dikembangkan dengan suatu grafik yang dapat 
melihat data pemeriksaan dan data pasien berdasarkan bulan yang dipilih, terdapat perhitungan yang lebih kompleks terkait BBS dan dapat menjadi sistem yang online.

\section{DAFTAR PUSTAKA}

[1] Prasetyo, Adit, dan Nanang Indardi. (2015). Peningkatan Keseimbangan Postural Menggunakan Pengukuran Berg Balance Scale (BBS) pada Lansia di Sasana Panti Mulyo Sragen. Journal of Sport Sciences and Fitness, 4(1).

[2] Prigianata, M. Malik. (2013). Sistem Informasi Posyandu Guna Mempermudah Pencatatan Pemeriksaan Berbasis Web. Journal of Information and Technology, 1(1).

[3] Nundy, Shantanu, Gaurav Singal, dkk. (2012). A Web-Based Patient Tool for Preventive Health. Journal of Primary Care and Community Health, 3, 289-294.

[4] Downs S, Marquez J, Chiarelli P. (2014). Normative Scores on the Berg Balance Scale Decline After Age 70 years in Healthy Community-Dwelling People: A Systematic Review. Journal of Physiotherapy, 60, 85-89.

[5] Langley, F.A., Mackintosh, S.F.H. (2007). Functional Balance Assessment Review of The Literature. The Internet
Journal of Allied Health Science and Practice, 5(4).

[6] Downs S, Marquez J, Chiarelli P. (2014). Normative Scores on the Berg Balance Scale Decline After Age 70 years in Healthy Community-Dwelling People: A Systematic Review. Journal of Physiotherapy, 60, 85-89.

[7] Pressman RS. (2010). Software Engineering : A Practitioner's Approach, 7th ed.Mc Graw Hill

[8] Binanto, Iwan. (2014). Analisa Metode Classic Life Cycle (Waterfall) untuk Pengembangan Perangkat Lunak Multimedia. Seminar Nasional Sains dan Teknologi Informasi, 33-38. 